\title{
Double Blind Study
}

National Cancer Institute

\section{Source}

National Cancer Institute. Double Blind Study. NCI Thesaurus. Code C15228.

A study method in which neither the subjects nor the investig ators are permitted to know which subject is receiving which treatment. 